\title{
ACTUALIZATION OF CHARACTER VALUES IN HISTORY LEARNING IN SENIOR HIGH SCHOOL OF YOGYAKARTA
}

Written by:

Febta Pratama, and Aman

Yogyakarta State University

Email: ayodhyaafebta@yahoo.com

\begin{abstract}
This research is aimed to: (1) identify character values which are actualized in history learning, (2) analyse the form of character values actualization which are actualized in history learning. This research is descriptive qualitative research with case study approach. Research sample is conducted using Purposive. Data analysis technique uses interactive analysis technique from Miles and Huberman which consist of data collection, data presentation and conclusion. The research findings show: (1) the values actualized in history learning are honesty, responsibility, love homeland, religious, discipline, curiosity, mutual respect, politeness, (2) the form of characteristic values actualization are statement admitting mistakes, congregation Zuhur pray, reciting Al-Quran, singing national anthem and hero songs before starting the lesson, attempting to get knowledge by asking.
\end{abstract}

Keyword: actualization, character values, history learning, senior high school 


\section{Introduction}

Article 3 of National Education System Acts stated that, national education functioned to develop capability and forming characteristics and dignified civilization. The point is Indonesian education want to develop any potential of the students (2003, p.3) including moral potential. The aspect of moral education or character education has important role in guiding students about character values which make the students a better person. Character, according to Lumpkin (2008, p.45), is described in the form of sportivity behaviour, respect for others, appreciate facilities, self-control, will, and responsibility. Munir (2010, p.3) stated that characters is a pattern, either thought, attitude, or action inherent on a person strongly and difficult to be removed.

Marzuki (2009, p.34), generally characters are divided into two; those are noble character (al-akhlaq-al mahmudah) and disgraceful character (al-akhlaq al mahmumah). Reviewed from its scope, character is divided into two; those are character towards Khaliq (Allah SWT) and creature character. This creature character is divided into three parts which are character to other human, character to other creatures such as plants and animals, and character to natural environment. Character education is an education which is sought to teach good values, then bring out and polish those good values as a characteristic of a person. Frye (2002, p.2) suggested character education as a national movement creating school that foster ethical, responsible and caring young people by modelling and teaching good character through an emphasis on universal values that we all shake.

Schwarts (2006,p.26) proposed that character education is often the umbrella term that describes concerted effort to teach a member of qualities, such as civic virtues, respect, and responsibility, social and emotional learning, empathy and caring, tolerance for diversity, and service to the community. Character education is education which describes the joint efforts to provide quality, such as respect and responsibility of social learning and emotional, empathy, and caring, tolerance toward diversity and community service. Character education is a strategic learning developing social and personal responsibility embodied by the development of good characters and moral virtues. Poerwanti stated that universal character values are value which can be accepted in every environment and culture (Poerwanti, 2013, p.32).

Character values applied universally and must be possessed by students are respect and responsibility. Respect has to be delivered in every interaction with surrounding environment. Allen (2009, p.595), "Respect is something that we give others; it means consideration for them and their needs as individuals." Children give their respect without considering with whom they going to give their respect including respect towards teachers during lesson hours and outside lesson hours. Respect is the initial value of students to understand and obtain other character values in school.

Responsibility for doing the tasks in earnest is character of every student. This responsibility character is very useful in daily life. In order to fulfil responsibilities, children must have capability to do tasks or jobs (Apriani, 2015, p.16). Every good parent will directly involve in educating students' character so that students have moral values. Grant (2013, p.63) stated that children of authoritative families tend to be independent, self-reliant, and responsible and to have prosocial behaviours, such as cooperation, sharing, and sympathy for others. Students need to get good behaviour in education to be able in absorbing and actualizing character values.

School has contribution and big role in building character. Starrat cited by Wibowo (2009, p.1) stated that there are three important role carried by school in schooling practices. Those roles include intellectual domain, moral domain, and social domain. Moral and social domain more leads to character building efforts.

Aman (2011, p.66) stated that history learning as subsystem of educational activity system is comparison efforts in learning activity that show the setting and organizing of teaching learning environment, thus 
encouraging and motivating students to study and develop themselves. The process of history learning is started from the beginning to the end of learning is full of character content.

Hasan (2012, p.89) stated that the material of history education is highly potential and even essential for developing nation character education. Therefore, the material of history education must be changed from materials that are rich of facts but low values to materials that can explain the reality of today life; emerging change direction; values, tradition, moral, fighting spirit exist in society when an event happen and still passed down to the present day.

Character values in history learning beyond universal character values are nationalism value, patriotism value, pluralism attitude, and mutual cooperation. This is what I call as general characters and special characters. History learning by teacher can be conducted using various ways, primarily to build students' character values. A research in United States found that by watching a movie in classroom can escalate characters such as empathy and critical thinking.

Donelly (2014, p.19) stated that this line of investigation began with the observation that attitudes to historical accuracies in feature films vary and that this impacted on the teachers' attitude and use of film. Film's ability to engage and to create interest by encouraging empathy and stimulating the historical imagination were the most reported rationales $(72 \%)$. encourages empathy (42\%), brings history to life - historical imagination and visual literacy $(30 \%)$. The research findings presented that film screening can build attitude such as empathy and make students highly imaginative.

Value is precious thing. Sapriya (2009, p.53) stated that value is a set of beliefs or behaviour principles that has personalized in oneself or certain group of people revealed when they are thinking or acting. A different opinion that is proposed by Linda is cited by Elmubarok (2008, p.7) saying that values can sorted into two; those are values of being and values of giving. Including in values of being are honesty, courage, peaceability, selfreliance, potential, discipline, moderation, purity, and conformity. Meanwhile, values of giving are values that need to be practiced or given then will be received as much as given.

This value group consists of loyalty, trustworthy, respect, love, sensitivity, unselfishness, kindness, friendliness, justice, and mercy. Mulyana (2011, p.11) stated that value is served as reference and belief in determining the choice. This reference can be norm, ethic, regulatory statutory, customs, religious rule, and other references which have value and perceived valuable for someone. Value by nature is abstract, behind the facts, creating actions, attached to someone's moral, appears as the end of psychological process and developed to more complex direction. Value in human can be showed by behaviour or the result of behaviour.

Lickona (1997, p.38) defined character values or moral values as something exist in one self. Thomas Lickona divided values into two; those are moral value and non-moral value. Moral value is value inside a person and mandatory performed. Moral value is divided into two; those are universal and nonuniversal. Universal moral value is general values that applied for others such as justice. Meanwhile, non-universal moral value is value that is only applied for the person himself such as honesty, responsibility, and belief. Nonmoral value is value that is not mandatory followed such as value of someone who likes something but other people do not necessarily like, for example is reading comic.

Hill in Stephenson (1983, p.3) argued that value is "when people speak of values they are usually referring to those beliefs held by individuals to which they attach special priority or worth, and by which they tend to order their lives. A value is, therefore, more than a belief, but it also more than a feeling." The opinion means that when people talk about value thus it basically refers to beliefs possessed individually and used as reference in determining main priority or appreciation so that they run a life based on those basic beliefs. Therefore, value is far more valuable than beliefs and feelings.

Pearson $(2000$, p.244) proposed that there are three main interrelated values. The three values as mentioned by Pearson are "these three areas focus on how individuals relate to self, others, and community at large. As school official identify lists of character traits to emphasize in their educational program, it 
might be useful to focus on these three areas of self, others, and community as they apply to their students. A focus on self could include such personal traits a responsibility, selfdiscipline. Three main values of character education by Pearson focus on the relationship between individual and himself, individual and others, and individual and community. Therefore, character values which should be instilled in and actualized are values related to those three main values such as responsibility, honesty, respect, and justice.

Kemendiknas (2010, p.13) through the centre of curriculum develops character values which have to be integrated in school curriculum, character values in divided into five key values; those are human behaviour values in relation to God the Almighty, values in relation to self, human relationship, human relationship with environment, and values which related to the spirit of nationality. Those values are divided into eighteen character values; those are religious, honesty, tolerance, discipline, hard work, creative, independent, democratic, curiosity, national spirit, love homeland, appreciate achievements, be friend, peaceability, keen to read, environmental care, social care, and responsibility.

Azra (2002, p.175) proposed that there are pillars or character values which are derived from universal values; those are, first, love of god characters and all his creatures. Second are independence and responsibility. Third are honesty/ trustworthy, diplomatic. Fourth are respect and polite. Fifth are generous, like helping, and mutual cooperation/ cooperation. Sixth are confidence and hard work. Seventh are kind and modest. Eighth are leadership and justice. Ninth are tolerance, peacefulness, and unity character. Those nine characters by Azra can be implemented with holistic education model, methods of knowing the good, feeling the good, and acting the good.

Character values must be able to be well actualized in self-student. However, students have to understand what is called actualization. Junarko (2012, p.19) argued that actualization is as actualizing, embodiment, realization, and implementation. Embodiment in this case is behaviour in daily life. Referring to the previous definition about actualization, then the actualization of character values is embodiment, realization, and implementation of character values.This character value actualization can only happen if the students either individual or group have capability and will. Thus, the character values become habituation. Students' habit that have get used themselves to good character means that the students have surpassed their natural needs.

Abraham Maslow in Cervone (2011, p.255) stated that the need of self-actualization is the highest need and the peak need of someone. If this need does not granted, the person will feel anxious and uneasy or even frustrated, although the person has been successful in other things. Maslow identified that someone who has reached selfactualization has the following characteristics: perception about reality, self-acceptance, spontaneity, task-oriented, autonomy, always appreciate life, engagement to humanity, deep interpersonal relationship, non-offensive sense of humour, and peak experiences.

Location of research shows that character values have been well actualized although it is not maximized. The character value actualization can be embodied because the habituation of character value internalization basically will be easy to be actualized. Character value actualizing need a long time and the result is permanent character value. Character value actualization in the research location is integrated with school culture and academics that support character education make the character values are easily actualized by the students.

The basic character education of school research location is either Islam or nationalism. Particularly for history subject, there are many characters that can be embedded. However, because of many things such as the lack of lesson hour for history subject, history subject scheduled in the end of school hour, and no outdoor history learning out of school and to historical object, the character values is not maximized particularly special character of history subject.

This research is aimed to (1) identify character values actualized in history learning, and (2) analyse the forms of character value actualization actualized in history learning.

\section{Method}

This research uses descriptive qualitative research method with case study approach because this research reveals the fact, interaction process, and events in social situation of character value actualization in history learning process in senior high school. 
This research takes place in Muhammdiyah 2 Senior High School of Yogyakarta which is located in Jalan Kapas, Semaki Umbulharjo Yogyakarta and Public 3 Senior High School of Yogyakarta which is located in Jalan Yos Sudarso, Yogyakarta.

Location determination is based on school culture, school location and history, and history teacher. School culture in both locations is different. The first one is Islamicbased and another one is nationalism-based. Both locations are close to history object and it is the history object itself, as well as the history teachers in the school are the expertise in creating history subject maket. This research is conducted for five months which is from February to June, 2016. This research period is used to collect data until the obtained data are considered complete as the research need.

The research subject is all school community in Muhammdiyah 2 Senior High School of Yogyakarta and Public 3 Senior High School of Yogyakarta. The determination of research subject is conducted using purposive which is using certain consideration. The research subject is the headmaster, teachers, and students.

Data collecting technique is carried out using interview, observation, and document analysis. Sugiyono (2014, p.319) stated that there are several kinds of interview; those are structured interview, semi-structured interview, and unstructured interview. Semi-structured interview is aimed to find more opened problems. In collecting data, the researchers uses interview technique and the interview used is in-depth interview.

Agustinova (2014, p.213) stated that indepth interview is flexible and open, unstructured tight, not in formal situation, and can be done repeatedly on the same research subject. This research uses in-depth interview as data collecting technique. For data validity, this research uses triangulation technique. Triangulation used is source triangulation and technique triangulation.

This research uses interactive data analysis technique from Miles and Huberman. Miles and Huberman in Sugiyono (2014: 337) proposed that activities in qualitative data analysis are conducted interactively and continuously lasted until complete, thus the data is saturated. Activities in data analysis are divided into data reduction, data display, and conclusion.

\section{Finding and Discussion}

The character values actualized in history learning

This research is attempted to explore and reveal what character values actualized by the students in history learning. Therefore, it is important for the researchers to know little about character in students' point of view. As expressed by one research subject who stated that character education is education which its basis is to create better nation character (S1. Interview, April 18 ${ }^{\text {th }}, 2016$ ).

The same statement about character education is also expressed by RAP. RAP stated that character education is learning process where someone will get good character in which the character is expected be able to build someone's personality (S8. Interview, May $\left.2^{\text {nd }}, 2016\right)$. According to the informant, character education is an effort to make human be better both in attitude and behavior. Character values are also important to be understood its mean and definition.

Informant $\mathrm{L}$ in his statement stated that value is good and bad measurement, so character value is good and bad measurement of someone's personality because I think character is personality itself (L, Interview, May $\left.2^{\text {nd }}, 2016\right)$. Actualization is embodiment over something in daily life context, thus character value actualization is embodiment of good and bad of someone's personality (Interview, May $2^{\text {nd }}, 2016$ ).

Throughout this research, the researchers found that during the process of history learning in the school of research location, the students showed diverse interest toward history subject. There were research subject who like and who do not really like. This is also influenced the continuity process of character value actualization done by the students. Throughout several times interviewing and observing, it was found that the students are very enthusiastic in history learning. However, the level of enthusiasm was diverse from one to another. Pedagogical ability possessed by teacher who taught also became determinant factor in character value actualization done by the students.

There are eighteen items of character values that must be implemented and 
actualized into each subject. This is accordance with what has become the decision of curriculum development of education ministry. Those eighteen character values must be present in the students and must accordance with what is in the teacher teaching guidelines. When conducting the research in the research location, the researchers found several character values that have been actualized in the students' daily life, particularly during history learning. Character values found from the result of interview, observation, and documentation during the research are as follow: (1) honest, (2) responsible, (3) discipline, (4) mutual respect, (5) love homeland, (6) religious, (7) curiosity, and (8) polite.

Guided by character value framework proposed by kemendiknas that divide character values into five main key characters, thus history learning has provide the portion of character value actualization as follow, first is character values in individual's relation and God are religious are someone's thoughts, words, and actions that are always attempted in the basis of godhead value and/or their religious' dogma. At this main point, history learning has succeeded actualizing the religious values and well actualized by the students during the process of history learning.

Second is character values in individual's relation and himself; those are honest which is behavior based on the efforts to make himself as a reliable person in the words, actions, and works either for himself or other parties. This value of honest has been well actualized by the students of both research locations. The value of responsible is someone's attitude and behavior to do his task and duty as he supposed to do for himself, community, environment (nature, social, cultural), country, and God the almighty. Both in Muhammdiyah 2 Senior High School of Yogyakarta and Public 3 Senior High School of Yogyakarta, responsibility has been instilled inside the students so that the actualization is very clear in the learning process. The character of discipline is an action that shows orderly and obedient behavior on various provisions and regulations.

This discipline character has not been maximally actualized well by all the students. However, most of students in both research locations have actualized this discipline value properly especially in the process of history learning. The value of curiosity is an attitude and action that always try to understand more deeply and broadly from what they learned, seen, and heard. The students' curiosity in both locations is very large. History subject is greatly favored by the students either by natural science's students or social science's students although majority the curiosity of social science's students toward history knowledge is bigger.

Third is character value in individual's relation and others. Polite value is a subtle and good attitude from the perspective of grammar and manner to everyone. Either in Muhammdiyah 2 Senior High School of Yogyakarta or Public 3 Senior High School of Yogyakarta, polite character value has been strongly instilled, not only in the outside learning but also during the process of learning has been well actualized.

Fourth is character value in individual's relationship and nationality which is love homeland character is way of thinking, behave, and act that show loyalty, caring, and high appreciation toward language, physical, social, cultural, economy, and political environment of his nation. Love homeland for both locations is acknowledged but has not been actualized. All students understand love for homeland; therefore there are partially students who more favor culture and customs from other countries, either their clothes, art, or technology, etc. This has bad impact for the next generation if history does not take important role in reintroducing national identity.

The forms of character value actualization in history learning

The forms of character values actualization in history learning in Muhammdiyah 2 Senior High School of Yogyakarta

First is honest. Honesty value of Muhammdiyah 2 Senior High School of Yogyakarta has been well actualized. When conducting interview with history teacher, the history teacher stated that the students, for honesty had been actualized, but they only needed little stimulus (G2. Interview, April $\left.22^{\text {th }}, 2016\right) . \quad$ In history learning, when observing class X IPA 1 and XI IPS 2, honesty values is highly visible on students' self. When observation is conducting in the class, the researchers found a student who had not done his homework whereas the homework would 
be discussed in that day. When being asked by the teacher, the student answered that he has not done the homework because he watched football last night (Observation, April 22 $2^{\text {th }}$, 2016). Interview was conducted accidentally with his several friends. The result showed that the student who the researchers interviewed also had not done his homework because he also watched football (S2, Interview, April 22th, 2016).

Second is responsibility. This responsibility character value is reflected in the students' daily life. This can be seen from their daily activities in learning. When doing observation in Muhammdiyah 2 Senior High School of Yogyakarta, the researchers found a student who did not do the task. The student was ordered to do substitute task by the teacher that must be submitted in the end of school hours. The researchers followed the student to find out whether he truly did the task.

Finally, the researchers found the student was doing the task in school canteen. Then, the researchers asked his friend about what is the student doing (Observation, May, 2016). In the end, the researchers found out that the student surely did the task ordered by the teacher. After school hours, the researchers spontaneously asked the teacher about the task and the teacher answered that the task has been submitted in his desk. (G2, Interview, May, 2016). The researchers finally make a conclusion that the student has responsibility over what he has done.

Third is discipline of Muhammdiyah 2 Senior High School of Yogyakarta which is a benchmark for private school is actually not much different than Public 3 Senior High School of Yogyakarta. In this senior high school, students' discipline is not highly visible either in their way of dressing or in the process of history learning. The researchers purposely observed from afar how the students' discipline was and the result is surprising. Many students had not entered classroom. Only after ten minutes entering the classroom, those students wore their uniform not neatly. However, the teacher would not allow the students to come in the class if they had not made up their uniform.

Seeing the phenomenon, the researchers then confirmed to the teacher whether the students often did such thing or they only did it especially in history subject hour. The teacher, SJD, stated that the students here were actually like that, average teachers complained about the same thing. That was the difficulty to ask students to enter the classroom (G1, Interview, April $\left.21^{\text {th }}, 2016\right)$. Then the researchers asked the students whether some students actually acted like that and the students answered that they are actually, coming late to classroom, too busy playing, then entering the classroom and it happen in all subject (S4. Interview, April $\left.21^{\text {th }}, 2016\right)$.

Fourth is mutual respect. Mutual respect in Muhammdiyah 2 Senior High School of Yogyakarta has not been maximally actualized. When their friends doing presentation in front of class, other students was busy preoccupied with themselves such as playing game in their mobile phone, chatting in media social, listening to the music, or even sleeping (Observation, April 21 th 2016 ). RS stated that the students' mutual respect has not formed yet. Even if it existed, it only existed in few people as an appreciation of their friends' effort doing presentation and it is usually done by the class champion (S5. Interview, April $21^{\text {th }}, 2016$ ).

History teacher stated that half of the students had not had mutual respect. If there were few students who respect their friends, it purely came from the students himself. I occasionally scolded so that they paid attention to their friends who did presentation while I was noting what they did (G1. Interview, April $\left.21^{\text {th }}, 2016\right)$.

Fifth is religious character. In, Muhammdiyah 2 Senior High School of Yogyakarta there is a reciting Quran program before starting teaching-learning activities. Salam (greeting) is good teaching in every religion. When doing observation in the classroom, the researchers found several students did not say salam when coming to the class, even they tend to enter the class carelessly. If there were some students who said salam, it was only chit chat even it was considered as a joke (Observation, May 10 $0^{\text {th }}$, 2016). Awareness of religious has not been visible in the students' self. School program in fact has not been able to make the students more religious. For example is Zuhur prayer. It was only few students who wanted to pray directly. When asking about the students' 
religious character, teacher DK stated that the students' religious inside the classroom was still less. Trivial thing such as coming late and did not say salam to the teacher that was teaching (G2. Interview, May 10 $0^{\text {th }}$, 2016).

Sixth is curiosity character. In history learning in Muhammdiyah 2 Senior High School of Yogyakarta, this curiosity character can be seen in discussion and presentation session. This curiosity basically presents critical stance. Curiosity can be seen from questions asked by the students. To prove the asked question, interview was conducted on the students of X IPA 1 . The student stated that "curiosity emerged in ourselves when we are interested in the materials being taught", (S7. Interview, April 22 $2^{\text {th }}, 2016$ ).

Seventh is politeness character. Politeness in Muhammdiyah 2 Senior High School of Yogyakarta slowly has been actualized by the students. In history learning, it can be seen during the observation that in term of politeness, the students seemly being forced. The politeness has been embodied by the students in greeting and kissing the hand of history teachers. The history teacher, Buk DK stated that politeness attitude is good enough, but it is only performed by several students and to the teachers that they know (G2. Interview, May $21^{\text {th }}, 2016$ ).

Student R stated that related to politeness value, generally politeness has not been actualized. But, only for history learning, half of the students are polite because the way the teacher teaching is fun and the students know him (S6. Interview, May 21 $\left.1^{\text {th }}, 2016\right)$. From the statement, it is reflected that politeness has been actualized by the students in history learning. It is only not entirely performed to all teachers.

Eighth is love homeland character. Love homeland as explained by the teacher SJD has been well embedded and well actualized by the students in Muhammdiyah 2 Senior High School of Yogyakarta. This can be seen when they stated that they were proud of Indonesian's culture and historical heritage and will keep and take care of it (G1. Interview, April 21 $\left.1^{\text {th }}, 2016\right)$. In history learning, the teacher SJD always told beforehand how Indonesian nation's struggle is from the ancient period to independence seizing period. By learning history, informant S2 stated that informant become more understand about Indonesia's history and become more proud as
Indonesian people because history taught what is not taught by other subjects which is identity of a nation including Indonesia (S2. Interview, April 23 ${ }^{\text {th }}$, 2016).

The forms of character value actualization in history learning in Public 3 Senior High School of Yogyakarta

First is honest. Honest is an important value in the process of building and actualizing character value. Throughout the research in the research location and during the actively or passively observation, the researchers believed that the character value actualized by the students in history learning is honesty value. In the location of Public 3 Senior High School of Yogyakarta, the researchers found honesty value is attempting to be embedded by history teacher with overseeing behaviour of the students either when doing tasks or when doing evaluation. In history learning, the researchers ever found a group of student does not create group assignment to be presented. Meanwhile, the day is their presentation day. When being asked by the teacher, they answered that they do not have time to create the assignment because they are too busy with other activities beyond school hours.

To prove whether they are honest or not, the researchers interview the teacher about how their daily activities looks like. The researchers do similar thing to those students and their theatre group. Finally, the researchers got an answer that they truly busy with other activities outside lesson hours (S3. Interview, April 23 th 2016 ). For this honest value, in, Public 3 Senior High School of Yogyakarta there is a program called "Pita Biru" which is a kind of honesty movement program. Pita Biru is used in examination or daily test as a sign that the student is honest in doing the task or test. And the more interesting thing is the Pita Biru program is not proposed by the teacher but purely students' movement who desire honesty in any behavior (G3. Interview, May 22th 2016 ).

Second is responsible character. Different thing happen in Public 3 Senior High School of Yogyakarta for responsible character value in the direct learning process. The researchers found a student asking for substitute task because he had not attended daily test. This incident made the researchers asking the history teacher, Mr. Is whether each student who studied history always asking for 
substitute task when they had not made it. The history teacher stated that here, responsibility has been well built when they felt that they had not made a task because of certain reason. They would come to their teacher to ask for substitute task (G3. Interview, April 19 ${ }^{\text {th }}$, 2016).

Feeling uncertain with the teacher's answer, the researchers tried to ask his classmate, and the student politely answered "We felt something's missing if we have not finished a task or cannot finish it because of certain reason. Therefore, we always ask for substitute task or supplementary test" (S4. Interview, April 22 $\left.{ }^{\text {th }}, 2016\right)$. According to the answer, the researchers believed that the student has high responsibility over their act.

Third is discipline character. In Public 3 Senior High School of Yogyakarta for instance, discipline has not been actualized by overall students. When doing observation in a class, the researchers found that when the history subject was starting, many students were still in the canteen. Only after five or ten minutes later, the students entered the class with various reasons. The researchers viewed the students' discipline need to be re-established by doing a kind of light punishment for the discipline embedded in the students' self. The researchers also asked the same thing to the history teachers and other teachers whether every student is always like that or it only happened in history subject hour. Teacher S stated that average in every lesson; the students often come late because they eat at the canteen. But, the students in SMA Negeri 3 Yogyakarta in term of dressing have been discipline. The discipline issue was only in discipline time in history learning.

Fourth is mutual respect character. In Public 3 Senior High School of Yogyakarta, mutual respect in the process of history learning does not seem really well. Only few students who are seem having mutual respect. This mutual respect can be seen during the presentation process in front of class. This mutual respect has not been well actualized by all students. There were many students who are preoccupied with themselves or with other friends. There were students who played mobile phone or talked with their next friend. Only few students who paid attention to their friends presenting in front of class as the form of mutual respect over their friends' hard work in doing their task (Observation, May 13 ${ }^{\text {th }}$, 2016).

This is expressed by student MR who stated that partially the students were care and appreciate what was done by their classmate who were presenting. It usually performed by class champion or classmate who fond of history learning. The rest are absorbed with themselves. They were playing mobile phone and listening to the music, and even sleeping although there were many factors causing the student to fall asleep (S7. Interview, May $13^{\text {th }}$, 2016). Teacher $S$ stated that he let the students did it to see their attitude because there were many students who active outside the class and of course I noted in my journal as consideration for assessment in the end of semester (Interview teacher $\mathrm{S}$, May $13^{\text {th }}$, 2016).

Fifth is religious character. Students of Public 3 Senior High School of Yogyakarta, during several observations, found that for salam, it had been well actualized by the students. When observing in XI IPA 2 May 2016, the religiosity side was identified. At that time, several students came late to class, and then they said salam and kissed the teacher's hand (Observasi, May 12 $2^{\text {th }}$ 2016). Such ways show religious attitude and respect toward older people. This attitude show high religious attitude even though not all students in the classroom were Muslim. Meanwhile, teacher S stated that religious attitude or character had been actualized from the beginning without teacher's intervention.

History learning according to the researchers only provides stimuli to actualize religious character, through materials, however the religious characters is common characters in all subjects. The sixth character of curiosity, the students of Public 3 Senior High School of Yogyakarta have actualized the character values, particularly from curiosity. The student of the SMA proposed questions to their teacher to gain explanation. Besides, the curiosity is also actualized by visiting library of browsing in the Internet related to the materials which the students have not understood (Observation, May 23 2016). The students stated that they often look for literature to accomplish material they like but less explanation (S5, Interview, May 15th 2016 ). 
The seventh character of politeness, in the history learning, it seems students if they want to get in or get out the classroom, they certainly will say greetings and get permission from the teachers. Along when the students get in the classroom, or get out the classroom, Public 3 Senior High School of Yogyakarta has a tradition of hands-greeting when starting and finishing history learning. To prove this finding, the researchers conducted observation many times in the other classes, and eventually the researchers found the same thing. The researchers also conducted interview to the history teachers in concern with this politeness culture. The history teachers told that the students here are quite polite. If any teacher pass surely they will be welcomed and kissed their hands as a part of respect to the older as well (Interview Teacher S. May 25 ${ }^{\text {th }}$ 2016).

From the teacher S's explanation, it implies that students in this SMA have already polite attitude. Then, interview was also conducted to the students in some class related with the politeness. Mostly students responded that what they did was not only in the history learning, but also in all subjects. In addition, they do it by themselves without any coercion or a part from respecting the older, (S4, S5, Interview, May 25 $5^{\text {th }}$ 2016).

The eighth character of patriotism, in the history learning, patriotism value is always embedded and actualized well by the students. In the learning process, the teachers always show documenter films about culture, richness and customs of Indonesia, then starting the class and inserting character values. Teacher $\mathrm{S}$ said that the students in Public 3 Senior High School of Yogyakarta have actualized patriotism value well. This is proven by their proud to wear domestic products such as batik, (G3. Interview, April 22 $2^{\text {th }}$ 2016). Informant L said that history teaches about patriotism, history provides knowledge about the origin of a regional identity, by learning history I came to know why there are temples, national monument, and oath youth event. By learning history I came to know how I can go to school here, (S3, Interview, April 21 ${ }^{\text {th }}$ 2016).

\section{Conclusion and Suggestion}

Conclusion

Actualization of character values in the history learning has been actualized well but not yet maximally. It should do some improvement in order to be actualized maximally. From the research result and discussion, it can be inferred that there is some character values which have not been actualized well by the students in history learning. The characters are namely, honesty, responsibility, discipline, mutual respect, patriotism, religious, curiosity, and politeness.

Form of the character values actualization depends on the individual students themselves, how they actualize the character values. Process of the actualization depends on how the result of students internalization. Some result and form of actualization are by confessing the pride of own nation's culture and art, such as wearing batik clothes. Religious value in the learning life can be seen from tolerance in religious life and sholat in the praying times. Then, the students are often and like reading as a part of curiosity.

Eventually, the researchers want to provide conclusion that actualization could not be conducted if the character values were not introduced, given comprehension and internalized in the students self, particularly in sense of character values in the history learning.

\section{Suggestion}

From the research result, there are some matters that can be suggested relation to the character values, such as school: this research is expected to be a reference to both schools Muhammadiyah 2 Senior High School and Public 3 Senior High School Yogyakarta to be able to develop strategy in embedding character values in each school. Along the research suggests that the teacher to design learning more and hold outdoor learning to history object and implement inquiry pattern to the students. For the students, this research can be a material to make themselves up, that indeed the education and nation moral is over the students' hand and they are expected to be more serious in absorbing and actualizing the character values

\section{References}

Abdullah Munir. (2010). Pendidikan karakter: membangun karakter anak sejak dari rumah. Yogyakarta. Pustaka Insan Madani.

Allen, J. \& Dennis, M. (2009). Dignity and respect matter. British Journal of Healthcare Assistants, 3 (12), 594-598.

Aman.(2011). Model evaluasi pembelajaran 
sejarah. Yogyakarta: Ombak.

Apriani, A., \& Wangid, M. (2015). Pengaruh SSP tematik-integratif terhadap karakter disiplin dan tanggung jawab siswa kelas III SD. Jurnal Prima Edukasia, 3(1), 1225. Retrieved from http://journal.uny.ac.id/index.php/jpe/art icle/view/4061

Azra, A. (2012). Paradigma baru pendidikan nasional rekonstruksi dan demokratisasi. Jakarta: Kompas.

Cervone, D.(2011). Personality: theory and research. A.b. aliya tusyani kepribadian (teori dan penelitian). Jakarta: Salemba Humanika.

Donnelly, D.(2014). "Using Feature Film in the Teaching of History: The Practitioner Decision-Making Dynamic". Journal of International Social Studies, Vol. 4, No. 1, , 17-27.

Agustinova, D.E.(2014). Diktat Pegangan Kuliah Metodelogi Penelitian Kualitatif Jilid 1 (Revisi). Yogyakarta: FIS UNY.

Elmubarok, Z. (2008). Membumikan pendidikan nilai: mengumpulkan yang terserak, menyambung yang terputus, dan menyatukan yang tercerai. Bandung: Alfabeta.

Frye, M. et.al. (2002). Character education: information handbook and guide for support and implementation of the student citizent act of 2001. North Carolina: Public Schools of North Carolina.

Grant, K. B. \& Ray, J. A. (2013). Home, school, and community collaboration: culturally responsive family engagement ( $2^{\text {nd }} e d$.). California: SAGE Publications, Inc.

Hasan, H.S.(2012). "Pendidikan sejarah untuk memperkuat pendidikan karakter". Paramita. Vol 22. No. 1. Hal. 85-97.
Junarko. (2012). Ahklak Dan Aktualisasinya Dalam Kehidupan. Diambil Tanggal 12 November 2015

Dari Http://Id.Scribd.Com/Doc/91122548/Ma kalah-Akhlak-Dan-Aktualisasinya.

Lickona, T. (1997). "The teachers role in character education". Journal of education, Vol 179. No. 4. Page. 63-78.

Lumpkin, A. (2008). "Teacher as role models teaching character and moral virtues". Journal of Physical Education Recreation and Dance, Vol. 72. No. 2. Pg. 45-58.

Marzuki. (2009). Prinsip dasar akhlak mulia: pengantar studi konsep-konsep dasar etika dalam Islam. Yogyakarta: Debut Wahana Press-FISE UNY.

Mulyana, R. (2011). Mengartikulasikan pendidikan nilai. Bandung: Alfabeta.

Nicholson,P.(2000)."Comperehensivecharacter education in the elementary school". Journal Of Humanistc, Conceling, educationand Development:Proquest Education Journal: Vol 38. No 4. Pg. 244.

Poerwanti E. (2013). Sistem indikator nilainilai moral universal sebagai evaluasi reflektif pendidikan karakter di TK. Jurnal Prima Edukasia, 1(1), 30-42. Retrieved from http://journal.uny.ac.id/index.php/jpe/ar icle/view/2314

Pusat Kurikulum Badan Penelitian Dan Pengembangan.(2010). Panduan pelaksanaan pembinaan pendidikan karakter di sekolah menengah pertama.Jakarta: Kementerian Pendidikan Nasional.

Republik Indonesia. (2003). Undang-Undang Republik Indonesia Nomor 20, Tahun 2003, tentang Sistem Pendidikan Nasional.

Sapriya.(2009). Pendidikan ips: konsep dan pembelajaran. Bandung: Remaja 
Rosdakarya Offset.

Schwartz, Beatty, Dachnowes. (2006).

"Character education: frill or foundation? Pricipal leadership". Proquest Education Journal. Vol 7. No. 4. Pg. 25-37.

Stephenson, J. (1998). Value of education. London: Hartolis.

Sugiyono. (2014). Metode penelitian pendidikan: pendekatan kuantitatif, kualitatif, dan $r \& d$. Bantung: Alfabeta.

Wibowo, T. (2009). Sekolah unggul, sekolah tidak unggul. Diambil Tanggal 23 November 2015 Dari .

\section{Brief Profile}

The $1^{\text {st }}$ Writer. Febta Pratama was born in Lubuk Ladung in February 1, 1993. The Bachelor degree was completed in 2015 at Study Program oh History Education, Yogyakarta State University. The Master degree was completed in 2017 at Study Program of History Education, Yogyakarta State University.

The $2^{\text {nd }}$ Writer. Dr. Aman, M.Pd, he was born in Brebes in February 15, 1974. The Bachelor degree was completed in 1999 at History Education, Yogyakarta State University. The Master degree was completed in 2002 at History Education, Jakarta State University. The Doctoral degree was completed in 2011 at Research and Evaluation of Education, Yogyakarta State University. 